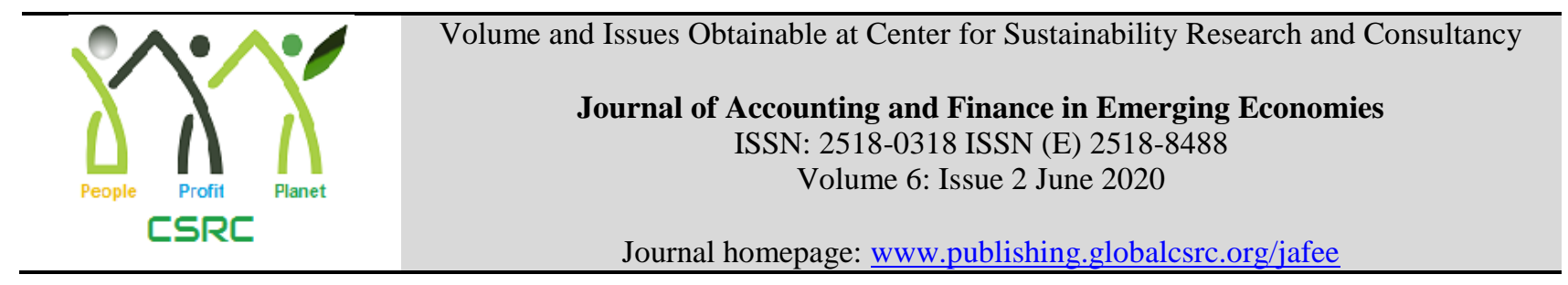

\title{
Financial Inclusion and Determinants in South Asian Countries
}

\author{
${ }^{1}$ Robina Badar, ${ }^{2}$ Sofia Anwar, ${ }^{3}$ Syed Asif Ali Naqvi \\ ${ }^{1}$ Ph.D. Scholar, Department of Economics, Government College University Faisalabad, Pakistan, \\ Robinaahmad2011@yahoo.com \\ ${ }^{2}$ Professor, Department of Economics, Government College University Faisalabad, Pakistan, \\ sofia_eco@gcuf.edu.pk \\ ${ }^{3}$ Assistant Professor, Department of Economics, Government College University Faisalabad, Pakistan, \\ asifalinaqvi@gcuf.edu.pk
}

\begin{tabular}{l}
\hline ARTICLE DETAILS \\
\hline History \\
Revised format: May 2020 \\
Available Online: June 2020 \\
\hline Keywords \\
Financial inclusion index; \\
economic growth; bank \\
accounts; insurance \\
\hline
\end{tabular}

JEL Classification

F3, F65

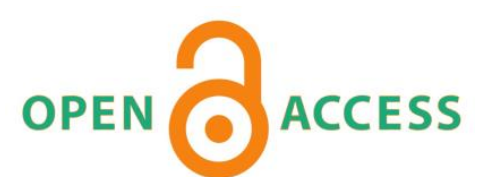

\begin{abstract}
Financial inclusion is considered an essential mediator to achieve economic growth in recent years. The main focus of this study is to construct the financial inclusion index and to explore the determinants of financial inclusion in Pakistan, Bangladesh, and India. Data is collected from InterMedia's financial inclusion insights datasets 2016 that are collected through random sampling. The financial inclusion index is used as a dependent variable that is calculated using levels of access and usage of financial services. Age, gender, education, financial situation, working type and use of mobile phones are used as independent variables. Results of multinomial logistic regression reveals that in South Asian countries educated, male, relatively older, rich and regular employees have a better chance to be financially included. Mobile phone users also prefer high financial inclusion. Developing countries like Pakistan, Bangladesh, and India can attain inclusive growth by increasing the contribution of weaker sections of the population with the mainstream. If weaker sections of the population have easy access to financial services, the economic growth of a country can be enlarged. So policymakers should focus on the financial sector's structural problems and pay attention to create modern financial institutes both in the banking sector and in financial markets.
\end{abstract}

(C) 2020 The authors, under a Creative Commons AttributionNonCommercial 4.0

Corresponding author's email address: sofia_eco@gcuf.edu.pk

Recommended citation: Badar, R., Anwar, S. \& Naqvi, S. A. A. (2020). Financial Inclusion and Determinants in South Asian Countries. Journal of Accounting and Finance in Emerging Economies, 6(2), 623-633

\section{Introduction}

Economic growth depends upon savings and savings associated positively with financial literacy (Margin and Trinh, 2019). South Asia is one of the richest continents in the world, in terms of natural resources including a tremendous human capital (Labor) with a unique climate. Despite all the above facts reality is that the most population of these countries is poor. To solve this paradox of development many research activities initiated and many development theories support that savings increase economic growth and development. It is documented that financial inclusion 
can increase economic growth and development by reducing poverty (Banerjee et al., 2015). Financial services access enables one to receive credit and enhance business and save more to expand investments to respond to economic shocks (Aket and Wilson, 2013). Access to agriculture finance is a powerful tool to fight poverty and to increase the income of the rural population in developing counters (James et al., 2016). Access to financial services is very low in developing countries. Low-cost accounts and reductions in documentation requirements may enable the population to assess financial services (Allen et al., 2012). World Bank declared to achieve universal financial access by 2020 . It means the acceptance of financial inclusion as a major tool for the process of economic growth. In India, the government is focusing to enhance financial inclusion through savings, deposits, credit, payments, insurance, and remittances. But many barriers lead to low financial inclusion and caused exclusion like unaffordable cost, lack of financial services, lack of awareness, low income, poverty and illiteracy (Chattopadhyay., 2011; crisil inclusive, 2014). Pakistan also initiated regulations in the policy of financial inclusion. In Pakistan financial inclusion is low. Only $10 \%$ of adults have bank accounts with formal financial institutes. $56 \%$ of adults not used any formal or informal financial product. $36 \%$ of adults save in Pakistan and only $4 \%$ of adults save at formal financial institutes, these statistics of Pakistan shows a very low level of financial inclusion. There are many reasons for this low financial inclusion like economic cycles, religious faith, gender inequality and growing informalities of the banking sector (Ramiz- Ur- Rehman, 2017). In Bangladesh financial inclusion is also very low. Only $31 \%$ of the adult population has an account at formal financial institutes. $45 \%$ of people are unbanked. The cost of financial services is high, weak rule of law, under development and higher income inequality are the main barriers in financial inclusion in Bangladesh. (Uddin et al., 2017).

As the world is moving from paper money to digital money but future success depends on secure financial services. Consumer risks are increasing due to broader trends in venture capital investments and the use of cryptocurrencies like bitcoin. So there is a need to check the access to financial services and more work to be done to increase financial inclusion. Hub of literature is found on financial inclusion in developed countries but limited literature in developing countries. Most of the work is done on the country level but in this study, we do work on individual level. Novelty in this work is that we have constructed the first time financial inclusion index to measure the level of financial inclusion using household data rather than the country level that is previously done. We study determinants of financial inclusion for a larger sample of individuals from Pakistan, Bangladesh, and India and also compare the level of financial inclusion in these countries. We use six measures of financial inclusion, including the number of bank accounts, use of ATMs and mobile money services, bank branch and ATMs access and insurance while previous research ignores the mobile money services. Previous literature is discussed in the second section that concludes different results through different approaches by using different variables. In the third section, we explained data and methodology to construct the financial inclusion index and an association between variables. In section fourth, we discuss results and discuss the level of financial inclusion in selected South Asian countries and section five concludes the paper.

\section{Literature Reviews}

Financial inclusion means the process of availing formal financial services with fair prices and low cost at the right time and place without any discrimination to the whole society (Sarma and Pais, 2011). Many studies are conducted on the access and availability of finance, issues, and policies, we discuss them in detail now. Margin and Trinh (2019) examined the determinants of financial literacy and their impact on financial inclusion in two low-income countriesCambodia and Vietnam. The study also analyzed the impact of financial literacy on savings. The study used survey data (OECD-INFE, 2015) conducted by indo-china research Ltd. Education level and financial literacy is significantly and positively associated with savings (financial inclusion). Asare et al., (2018) analyzed the determinates of choice of savings (financial inclusion) in Africa by using the survey data from the World Global Financial inclusion (global findex) database, 2014. Multinomial model results showed that female entrepreneurs have less financial inclusion and educated male have more financial inclusion. Rue and Mojica (2018) examined how people choose to finance from informal credit markets by using multinomial logit and relative risk ratio by using survey data. James et al., (2016) evaluated the financial services providers' effect on agricultural performance in Kenya. Results reveal that the use of agent banking services had a good effect on per acre production margin than other services providers. The age of household head have also a significant effect on the choice of use of financial services. High-income households preferred to use conventional banking services. The cost of use and distance to the bank also impact the use of 
banking services. Roy and Chatterjee (2016) examined the research to identified the determinants of financial inclusion and invest Bangal and India by using survey data conducted in 2010. A multinomial logistics model is used to find out the main determinants. Results show that the prime mover of financial inclusion is income. Lack of adequate saving is one of the major causes to have no access to saving instruments. This is also due to the lack of financial literacy. The study suggests the policymakers to enhance the financial institutes and make it feasible to access to financial services by poor population. Sec and Ismail (2016) analyzed the determinants preferences for financial products by businessmen for resource mobilization in the Malaysian Islamic banking system. The multinomial discrete choice methodology is used to find out results by using a survey of 1858 retail consumers. Results showed that income, education, gender, and Islam (religious) positively impact the preference regarding saving accounts. Ampodia and Ehrmann (2015) examined the determinants of financial inclusion and exclusion in the euro area and the United States. Local survey data is used for the euro area household finance and data for the United States is collected by the US Survey of consumer finance, 2010. Results showed that savings and borrowings are important instruments of financial inclusion. One more reason is the wealth gap that affects owning a bank account or not. Maina (2012) studied the determinants of financial services to reduce poverty in Kenya. Multinomial logistic regression results show that households who use agent banking services make higher profits.

Wachira and Kihiu (2012) examined the impact of financial literacy on access to financial services by using the national financial access survey data 2009 in Kenya. Multinomial results show a low level of financial literacy in Kenya. High income is positively related to access to financial services. Increased financial literacy would help households to make good decisions regarding financial services. Von and Barasinska (2011) investigated the determinants of financial inclusion by using survey data collected by a survey of household income and wealth and Dutch household survey. By using multinomial logit results indicate that gender plays not any important role in the propensity for risk-taking during investment because gender does not matter but there is low participation in the market due to self-selection. Ellis et al (2010) examined the impact of access to financial services on the investment of households by using the fin scope household survey data of Kenya and Tanzania (2006 and 2009) data. Results showed that financial services are used more for investment purposes. So it is necessary to established and enhanced the formal financial services by the government. High chargers, lack of financial literacy, lack of nearby financial services, faculty and lack of required documentation are the main barriers.

The above-discussed literature review suggests that there are many studies to measure the level of financial inclusion. Most studies provide analysis on the country and regional level to find out the determinants of financial inclusion as ( Demirguc Kunt and Klapper, 2015), (Aterido, Beck and Iacovone, 2011). Some studies focus on individuals levels are Fungacova and Weill ( 2015), Zins and weill (2016). But Allen et al.,(2016), Park and Mercado (2018) and La Chu (2019) examined both individuals and country-level determinants of financial inclusion. Some studies use indices with different approaches to investigate financial inclusion. Account ownership, savings, insurance, and financial literacy are used as a proxy for financial inclusion.

\section{Data and Methodology}

This study attempts to construct a financial inclusion index, by taking into account the previous literature. The present study uses the Inter Media's Financial Inclusion Insights datasets 2016 of selected South Asian countries including Pakistan, India, and Bangladesh. Data covered 6000 adults of Pakistan, 45540 adults of India and 6000 adults of Bangladesh. Survey data is collected from Kantar's financial inclusion insights (FII) website that is organized in 2013 by the partnership with the Bill and Malinda Gates Foundation to build a financial landscape in eight countries across Africa and Asia. The interactive data provides all the information that we can use during analysis according to requirements. The survey on financial inclusion and access provides a large number of indicators on financial inclusion--- micro-level information which seeks to measure the access and use of financial services by all adults age 15 and above across financial situation and other demographics. The financial inclusion index (FII) is constructed that is used as a dependent variable in this study. For the construction of the financial inclusion index, the present study uses different dimensions. For which the following formula is used.

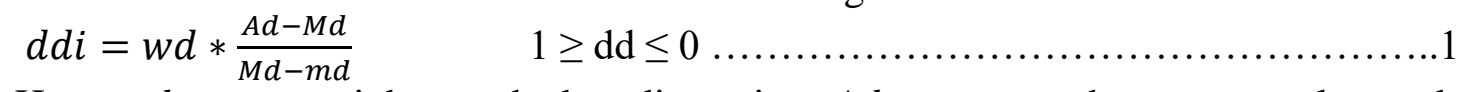

Here, $w d$ means weight attached to dimension, $A d$ represents the present value, md minimum value, $M d$ maximum value and $d d$ dimensions of financial inclusion $\mathrm{d}$ and $\mathrm{i}$ is used for each country. For the construction of financial 
inclusion, each dimension is equally important so we have given equal weight to each dimension. And 1 weight is assigned to each dimension. After assigning weight and using the normalization formula, the value of each dimension is calculated for each country. Higher the value of $d d$, the higher the countries achievement in this dimension. If there are $\mathrm{n}$ dimensions, then any country will be represented by $\mathrm{Di}=(\mathrm{d} 1, \mathrm{~d} 2, \mathrm{~d} 3, \ldots, \mathrm{dn})$ on the $\mathrm{n}$-dimensional Cartesian space.

After finding the values of each dimension, the average Euclidian distance formula is used to find out the distance between values of 0 and $X$. Point $X=(1,1,1 \ldots)$ represents the ideal situation and $0=(0,0,0 \ldots)$ represents the worst situation. If the gap between 0 and $\mathrm{x}$ is wide, it means high financial inclusion. If the gap is narrow, it signifies low financial inclusion (Goel and Sharma, 2017).

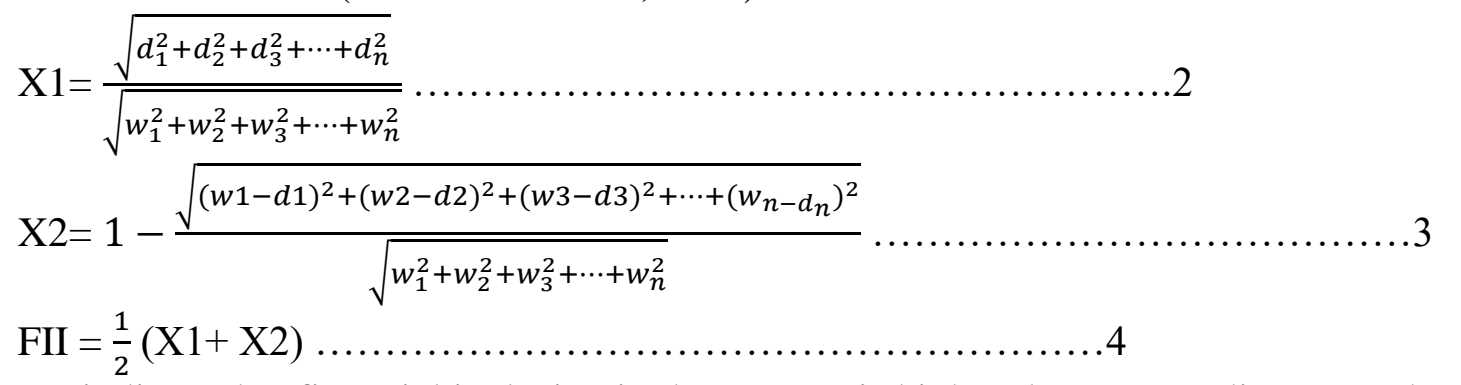

FII indicate that financial inclusion in the country is high or low. Depending upon the value

1. $0 \geq \mathrm{FII} \leq 0.4 \quad$ indicate low financial inclusion (LFI)

2. $0.41 \geq$ FII $\leq 0.6$ indicate medium financial inclusion (MFI)

3. $0.61 \geq \mathrm{FII} \leq 1 \quad$ indicate high financial inclusion (HFI)

Source: Values used by Goel and Sharma (2017).

Bank account ownership, bank branch access, use of ATMs, use of mobile money services, ATM access and insurance are variables used for the construction of financial inclusion index. The study aims to measure the determinants of financial inclusion in Pakistan, India, and Bangladesh. To evaluate the determinants we perform a Multinomial logistic model. Age, gender, education, financial situation, working type and use of mobile phones are used as independent variables.

FII $_{i}=\alpha+\beta^{*}$ Age $_{i}+\gamma^{*}$ Gender $_{i}+\delta^{*}$ Education $_{i}+\rho^{*}$ f. $_{\text {situation }}+\sigma^{*} W$ type $_{i}+\omega^{*}$ phone $_{i}+\epsilon_{i}$ ................................................................5

The dependent variable financial inclusion index (FII) is a categorical placement on multiple independent variables. The dependent variable has classified into three categories that is low financial inclusion, medium financial inclusion, and high financial inclusion. To evaluate the probability of categorical membership, multinomial regression uses maximum likelihood estimation. For each category of the dependent variable, the effect of the independent variable is different. In the multinomial logit model, one category of the dependent variable is taken as the reference category it may be first, last or the category with the highest occurrence.

\section{Results and Discussion}

Financial inclusion index (FII) be used to compare the degree of financial inclusion in different countries. Results showed that the level of financial inclusion is low in these South Asian countries.

Table 1 Level of financial inclusion in selected South Asian countries

\begin{tabular}{|c|c|c|c|}
\hline Countries & $\begin{array}{c}\text { Value of financial } \\
\text { inclusion index (FII) }\end{array}$ & $\begin{array}{c}\text { Financial inclusion } \\
\text { range }\end{array}$ & Category \\
\hline Pakistan & 0.34 & $0 \geq$ FII $\leq 0.4$ & Low financial inclusion \\
\hline Bangladesh & 0.37 & $0 \geq$ FII $\leq 0.4$ & Low financial inclusion \\
\hline India & 0.39 & $0 \geq$ FII $\leq 0.4$ & Low financial inclusion \\
\hline
\end{tabular}

Source: author' own calculations

In table 1 financial inclusion index represents the level of financial inclusion in Pakistan, Bangladesh, and India. According to the above-discussed method, the values of each dimension are calculated to measure the financial inclusion index (following eq.1). In this table, the second column represents the values of the financial inclusion index, is calculated by using the Euclidian distance formula (following eq.4). Countries are grouped into three categories by keeping in view the values of the financial inclusion index. The first category is high financial inclusion (HFI), the second category means medium financial inclusion (MFI) and the third one is low financial inclusion (LFI). 
FII score from 0.6 to 1 means high financial inclusion. If the FII score lies between 0.4 and 0.6 , then it means medium financial inclusion. If the FII score lies 0 to 0.4 , then it is categorized as low financial inclusion. The third column represents the range used by (Goal and Sharma, 2017) to measure the level of financial inclusion, and the fourth column indicates the low level of financial inclusion in Pakistan, Bangladesh, and India.

As we come to know that financial inclusion is low in these countries. To identify the determinants of financial inclusion in selected South Asian countries, Pakistan, India, and Bangladesh respectively a multinomial regression model is utilized. 
Table: 2 Description of variables regarding financial inclusion in Pakistan, Bangladesh, and India

\begin{tabular}{|c|c|c|c|c|c|c|c|c|c|c|c|c|c|}
\hline \multirow{4}{*}{\multicolumn{2}{|c|}{ Independent Variables }} & \multicolumn{12}{|c|}{ Financial inclusion (fi) } \\
\hline & & \multirow{2}{*}{\multicolumn{4}{|c|}{ Pakistan }} & \multirow{2}{*}{\multicolumn{4}{|c|}{ India }} & \multirow{2}{*}{\multicolumn{4}{|c|}{ Bangladesh }} \\
\hline & & & & & & & & & & & & & \\
\hline & & Low fi & $\begin{array}{l}\text { Medium } \\
\text { fi }\end{array}$ & High fi & Total & Low fi & $\begin{array}{l}\text { Medium } \\
\text { fi }\end{array}$ & High fi & Total & Low fi & Medium fi & High fi & Total \\
\hline \multirow{3}{*}{ GENDER } & Female $=0$ & $\begin{array}{c}2779 \\
(94.1) \\
\end{array}$ & $\begin{array}{r}159 \\
(5.4) \\
\end{array}$ & $\begin{array}{c}16 \\
(0.5) \\
\end{array}$ & $\begin{array}{l}2954 \\
(100)\end{array}$ & $\begin{array}{l}16005 \\
(65.8) \\
\end{array}$ & $\begin{array}{c}7396 \\
(30.4) \\
\end{array}$ & $\begin{array}{c}920 \\
(3.8) \\
\end{array}$ & $\begin{array}{r}24321 \\
(100)\end{array}$ & $\begin{array}{c}1475 \\
(54.2) \\
\end{array}$ & $\begin{array}{c}576 \\
(21.2) \\
\end{array}$ & $\begin{array}{c}672 \\
(24.7) \\
\end{array}$ & $\begin{array}{l}2723 \\
(100) \\
\end{array}$ \\
\hline & Male $=1$ & $\begin{array}{c}2522 \\
(82.8)\end{array}$ & $\begin{array}{c}452 \\
(14.8)\end{array}$ & $\begin{array}{c}72 \\
(2.4)\end{array}$ & $\begin{array}{l}3046 \\
(100)\end{array}$ & $\begin{array}{l}11849 \\
(55.8)\end{array}$ & $\begin{array}{c}7686 \\
(36.2)\end{array}$ & $\begin{array}{l}1684 \\
(7.9)\end{array}$ & $\begin{array}{r}21219 \\
(100)\end{array}$ & $\begin{array}{c}2407 \\
(73.5)\end{array}$ & $\begin{array}{c}448 \\
(13.7)\end{array}$ & $\begin{array}{c}422 \\
(12.9)\end{array}$ & $\begin{array}{l}3277 \\
(100)\end{array}$ \\
\hline & & \multicolumn{4}{|c|}{$\begin{array}{c}\text { Chi Sq. Value }=1.872 * * * \\
\text { Gamma }=0.53\end{array}$} & \multicolumn{4}{|c|}{$\begin{array}{c}\text { Chi Sq. Value }=6.415 * * * \\
\text { Gamma }=0.21\end{array}$} & \multicolumn{4}{|c|}{$\begin{array}{c}\text { Chi Sq. Value }=2.478 * * * \\
\text { Gamma }=-0.38\end{array}$} \\
\hline \multirow{4}{*}{ AGE } & $\begin{array}{c}\text { Less than } 25 \\
\text { years }=1\end{array}$ & $\begin{array}{c}728 \\
(91.6) \\
\end{array}$ & $\begin{array}{r}66 \\
(8.3) \\
\end{array}$ & $\begin{array}{c}1 \\
(0.1) \\
\end{array}$ & $\begin{array}{c}795 \\
(100) \\
\end{array}$ & $\begin{array}{r}4600 \\
(56.6) \\
\end{array}$ & $\begin{array}{l}3183 \\
(39.2)\end{array}$ & $\begin{array}{c}338 \\
(4.20\end{array}$ & $\begin{array}{l}8121 \\
(100)\end{array}$ & $\begin{array}{c}615 \\
(72.4)\end{array}$ & $\begin{array}{c}157 \\
(18.5)\end{array}$ & $\begin{array}{c}77 \\
(9.1)\end{array}$ & $\begin{array}{r}849 \\
(100)\end{array}$ \\
\hline & $26-50$ Years $=2$ & $\begin{array}{c}3976 \\
(87.6)\end{array}$ & $\begin{array}{c}484 \\
(10.7) \\
\end{array}$ & $\begin{array}{c}77 \\
(1.7) \\
\end{array}$ & $\begin{array}{l}4537 \\
(100)\end{array}$ & $\begin{array}{l}17578 \\
(33.8)\end{array}$ & $\begin{array}{l}10004 \\
(33.8)\end{array}$ & $\begin{array}{l}1980 \\
(6.7)\end{array}$ & $\begin{array}{r}29562 \\
(100)\end{array}$ & $\begin{array}{c}2463 \\
(60.6)\end{array}$ & $\begin{array}{c}742 \\
(18.2)\end{array}$ & $\begin{array}{c}861 \\
(21.2) \\
\end{array}$ & $\begin{array}{l}4066 \\
(100)\end{array}$ \\
\hline & $\begin{array}{c}\text { Above } 50 \text { Years }= \\
3\end{array}$ & $\begin{array}{c}597 \\
(89.4)\end{array}$ & $\begin{array}{c}61 \\
(9.1)\end{array}$ & $\begin{array}{c}10 \\
(1.5)\end{array}$ & $\begin{array}{c}668 \\
(100)\end{array}$ & $\begin{array}{c}5676 \\
(72.2)\end{array}$ & $\begin{array}{c}1895 \\
(24.1)\end{array}$ & $\begin{array}{c}286 \\
(3.6)\end{array}$ & $\begin{array}{l}7857 \\
(100)\end{array}$ & $\begin{array}{c}804 \\
(74.1)\end{array}$ & $\begin{array}{c}125 \\
(11.5)\end{array}$ & $\begin{array}{c}156 \\
(14.4)\end{array}$ & $\begin{array}{l}1085 \\
(100)\end{array}$ \\
\hline & & \multicolumn{4}{|c|}{$\begin{array}{c}\text { Chi Sq. Value }=17.204 * * \\
\text { Gamma }=0.08\end{array}$} & \multicolumn{4}{|c|}{$\begin{array}{c}\text { Chi Sq. Value }=6.295 * * * \\
\text { Gamma }=-0.16\end{array}$} & \multicolumn{4}{|c|}{$\begin{array}{c}\text { Chi Sq. Value }=1.245 * * * \\
\text { Gamma }=-0.02\end{array}$} \\
\hline \multirow{4}{*}{ EDUCATION } & Less educated $=1$ & $\begin{array}{l}3195 \\
(94)\end{array}$ & $\begin{array}{r}189 \\
(5.6)\end{array}$ & $\begin{array}{c}15 \\
(0.4)\end{array}$ & $\begin{array}{l}3399 \\
(100)\end{array}$ & $\begin{array}{l}14295 \\
(70.6)\end{array}$ & $\begin{array}{l}5543 \\
(27.4)\end{array}$ & $\begin{array}{l}399 \\
(2)\end{array}$ & $\begin{array}{r}20237 \\
(100)\end{array}$ & $\begin{array}{c}2601 \\
(75.7)\end{array}$ & $\begin{array}{c}511 \\
(14.9)\end{array}$ & $\begin{array}{c}325 \\
(9.5)\end{array}$ & $\begin{array}{l}3437 \\
(100) \\
\end{array}$ \\
\hline & $\begin{array}{c}\text { Medium } \\
\text { educated }=2\end{array}$ & $\begin{array}{c}1827 \\
(85.3) \\
\end{array}$ & $\begin{array}{c}291 \\
(13.6) \\
\end{array}$ & $\begin{array}{c}25 \\
(1.2) \\
\end{array}$ & $\begin{array}{l}2143 \\
(100) \\
\end{array}$ & $\begin{array}{l}13342 \\
(54.1) \\
\end{array}$ & $\begin{array}{r}9287 \\
(37.6) \\
\end{array}$ & $\begin{array}{l}2052 \\
(8.3)\end{array}$ & $\begin{array}{r}24681 \\
(100) \\
\end{array}$ & $\begin{array}{r}1098 \\
(54.5) \\
\end{array}$ & $\begin{array}{c}395 \\
(19.6) \\
\end{array}$ & $\begin{array}{c}523 \\
(25.9) \\
\end{array}$ & $\begin{array}{l}2016 \\
(100) \\
\end{array}$ \\
\hline & Highly educated $=3$ & $\begin{array}{c}279 \\
(60.9)\end{array}$ & $\begin{array}{c}131 \\
(28.6)\end{array}$ & $\begin{array}{c}48 \\
(10)\end{array}$ & $\begin{array}{c}458 \\
(100)\end{array}$ & $\begin{array}{c}217 \\
(34.9)\end{array}$ & $\begin{array}{c}252 \\
(40.5)\end{array}$ & $\begin{array}{c}153 \\
(24.6)\end{array}$ & $\begin{array}{c}622 \\
(100)\end{array}$ & $\begin{array}{c}183 \\
(33.5)\end{array}$ & $\begin{array}{l}118 \\
(21.6)\end{array}$ & $\begin{array}{l}246 \\
(45)\end{array}$ & $\begin{array}{c}547 \\
(100)\end{array}$ \\
\hline & & \multicolumn{4}{|c|}{$\begin{aligned} \text { Chi Sq. Value } & =5.812 * * * \\
\text { Gamma } & =0.57\end{aligned}$} & \multicolumn{4}{|c|}{$\begin{array}{c}\text { Chi Sq. Value }=2.109 * * * \\
\text { Gamma }=0.36\end{array}$} & \multicolumn{4}{|c|}{$\begin{array}{c}\text { Chi Sq. Value }=6.286 * * * \\
\text { Gamma }=0.48\end{array}$} \\
\hline \multirow{4}{*}{$\begin{array}{l}\text { FINANCIAL } \\
\text { SITUATION }\end{array}$} & Poor $=1$ & $\begin{array}{c}321 \\
(91.7)\end{array}$ & $\begin{array}{c}27 \\
(7.7)\end{array}$ & $\begin{array}{c}2 \\
(0.6)\end{array}$ & $\begin{array}{c}350 \\
(100)\end{array}$ & $\begin{array}{c}10436 \\
(71)\end{array}$ & $\begin{array}{c}3900 \\
(26.5)\end{array}$ & $\begin{array}{l}365 \\
(2.5)\end{array}$ & $\begin{array}{l}14701 \\
(100)\end{array}$ & $\begin{array}{c}1364 \\
(76.1)\end{array}$ & $\begin{array}{c}294 \\
(16.4)\end{array}$ & $\begin{array}{l}134 \\
(7.5)\end{array}$ & $\begin{array}{l}1792 \\
(100)\end{array}$ \\
\hline & Middle class $=2$ & $\begin{array}{c}2673 \\
(90.5)\end{array}$ & $\begin{array}{r}249 \\
(8.4) \\
\end{array}$ & $\begin{array}{l}30 \\
(1)\end{array}$ & $\begin{array}{l}2952 \\
(100)\end{array}$ & $\begin{array}{r}8750 \\
(60.8) \\
\end{array}$ & $\begin{array}{l}5011 \\
(34.8) \\
\end{array}$ & $\begin{array}{c}628 \\
(4.4) \\
\end{array}$ & $\begin{array}{r}14389 \\
(100)\end{array}$ & $\begin{array}{l}1772 \\
(66)\end{array}$ & $\begin{array}{c}465 \\
(17.3) \\
\end{array}$ & $\begin{array}{c}448 \\
(16.7) \\
\end{array}$ & $\begin{array}{l}2685 \\
(100)\end{array}$ \\
\hline & Rich $=3$ & $\begin{array}{c}2307 \\
(85.5)\end{array}$ & $\begin{array}{c}335 \\
(12.4)\end{array}$ & $\begin{array}{c}56 \\
(2.1)\end{array}$ & $\begin{array}{l}2698 \\
(100)\end{array}$ & $\begin{array}{c}8668 \\
(52.7)\end{array}$ & $\begin{array}{c}6171 \\
(37.5)\end{array}$ & $\begin{array}{l}1611 \\
(9.8)\end{array}$ & $\begin{array}{l}16450 \\
(100)\end{array}$ & $\begin{array}{l}746 \\
(49)\end{array}$ & $\begin{array}{c}265 \\
(17.4)\end{array}$ & $\begin{array}{c}512 \\
(33.6)\end{array}$ & $\begin{array}{l}1523 \\
(100)\end{array}$ \\
\hline & & \multicolumn{4}{|c|}{$\begin{array}{c}\text { Chi Sq. Value }=41.518 * * * \\
\text { Gamma }=0.23\end{array}$} & \multicolumn{4}{|c|}{$\begin{array}{c}\text { Chi Sq. Value }=1.529 * * * \\
\text { Gamma }=0.26\end{array}$} & \multicolumn{4}{|c|}{$\begin{array}{c}\text { Chi Sq. Value }=4.105 * * * \\
\text { Gamma }=0.36\end{array}$} \\
\hline $\begin{array}{l}\text { Mobile phone } \\
\text { use }\end{array}$ & $\begin{array}{l}\text { Have not mobile } \\
\text { phone }=1\end{array}$ & $\begin{array}{c}2551 \\
(97.1)\end{array}$ & $\begin{array}{c}73 \\
(2.8)\end{array}$ & $\begin{array}{c}4 \\
(2.5)\end{array}$ & $\begin{array}{l}2628 \\
(100)\end{array}$ & $\begin{array}{l}15465 \\
(66.8)\end{array}$ & $\begin{array}{c}7118 \\
(30.8)\end{array}$ & $\begin{array}{c}556 \\
(2.4)\end{array}$ & $\begin{array}{c}23139 \\
(100)\end{array}$ & $\begin{array}{c}3232 \\
(86.3)\end{array}$ & $\begin{array}{c}191 \\
(5.1)\end{array}$ & $\begin{array}{c}322 \\
(8.6)\end{array}$ & $\begin{array}{c}3745 \\
(100)\end{array}$ \\
\hline
\end{tabular}




\begin{tabular}{|c|c|c|c|c|c|c|c|c|c|c|c|c|c|}
\hline & $\begin{array}{l}\text { Have mobile } \\
\text { phone }=2\end{array}$ & $\begin{array}{l}2750 \\
(81.6)\end{array}$ & $\begin{array}{l}538 \\
(16)\end{array}$ & $\begin{array}{c}84 \\
(2.5)\end{array}$ & $\begin{array}{l}3372 \\
(100)\end{array}$ & $\begin{array}{l}12389 \\
(55.3)\end{array}$ & $\begin{array}{c}7964 \\
(35.6)\end{array}$ & $\begin{array}{l}2048 \\
(9.1)\end{array}$ & $\begin{array}{l}22401 \\
(100)\end{array}$ & $\begin{array}{c}650 \\
(28.8)\end{array}$ & $\begin{array}{c}833 \\
(36.9)\end{array}$ & $\begin{array}{c}772 \\
(34.2)\end{array}$ & $\begin{array}{l}2255 \\
(100)\end{array}$ \\
\hline & & \multicolumn{4}{|c|}{$\begin{array}{c}\text { Chi Sq. Value }=3.472 * * * \\
\text { Gamma }=0.76\end{array}$} & \multicolumn{4}{|c|}{$\begin{array}{c}\text { Chi Sq. Value }=1.230 * * * \\
\text { Gamma }=0.26\end{array}$} & \multicolumn{4}{|c|}{$\begin{array}{c}\text { Chi Sq. Value }=2.062 * * * \\
\text { Gamma }=0.79\end{array}$} \\
\hline \multirow{4}{*}{$\begin{array}{l}\text { WORKING } \\
\text { TYPE }\end{array}$} & Unemployed=1 & $\begin{array}{l}2944 \\
(93.8)\end{array}$ & $\begin{array}{c}180 \\
(5.7)\end{array}$ & $\begin{array}{c}14 \\
(0.4)\end{array}$ & $\begin{array}{l}3138 \\
(100)\end{array}$ & $\begin{array}{l}14850 \\
(64.2)\end{array}$ & $\begin{array}{l}7401 \\
(32)\end{array}$ & $\begin{array}{l}887 \\
(3.8) \\
\end{array}$ & $\begin{array}{l}23138 \\
(100)\end{array}$ & $\begin{array}{l}2431 \\
(72.6)\end{array}$ & $\begin{array}{c}484 \\
(14.5)\end{array}$ & $\begin{array}{c}433 \\
(12.9)\end{array}$ & $\begin{array}{l}3348 \\
(100)\end{array}$ \\
\hline & Self-employed $=2$ & $\begin{array}{r}1389 \\
(84.7) \\
\end{array}$ & $\begin{array}{c}228 \\
(13.9) \\
\end{array}$ & $\begin{array}{c}22 \\
(1.3) \\
\end{array}$ & $\begin{array}{l}1639 \\
(100) \\
\end{array}$ & $\begin{array}{l}2050 \\
(60.3) \\
\end{array}$ & $\begin{array}{c}1048 \\
(30.8) \\
\end{array}$ & $\begin{array}{c}304 \\
(8.9) \\
\end{array}$ & $\begin{array}{l}3402 \\
(100) \\
\end{array}$ & $\begin{array}{l}699 \\
(54) \\
\end{array}$ & $\begin{array}{c}274 \\
(21.2) \\
\end{array}$ & $\begin{array}{c}321 \\
(24.8) \\
\end{array}$ & $\begin{array}{l}1294 \\
(100) \\
\end{array}$ \\
\hline & $\begin{array}{c}\text { Salaried } \\
\text { employed }=3\end{array}$ & $\begin{array}{c}968 \\
(79.1)\end{array}$ & $\begin{array}{c}203 \\
(16.6)\end{array}$ & $\begin{array}{c}52 \\
(4.3)\end{array}$ & $\begin{array}{l}1223 \\
(100)\end{array}$ & $\begin{array}{l}10954 \\
(57.7)\end{array}$ & $\begin{array}{c}6633 \\
(34.9)\end{array}$ & $\begin{array}{l}1413 \\
(7.4)\end{array}$ & $\begin{array}{l}19000 \\
(100)\end{array}$ & $\begin{array}{c}752 \\
(55.4)\end{array}$ & $\begin{array}{c}266 \\
(19.6)\end{array}$ & $\begin{array}{l}340 \\
(25)\end{array}$ & $\begin{array}{l}1358 \\
(100)\end{array}$ \\
\hline & & \multicolumn{4}{|c|}{$\begin{array}{c}\text { Chi Sq. Value }=2.446 * * * \\
\text { Gamma }=0.45\end{array}$} & \multicolumn{4}{|c|}{$\begin{array}{c}\text { Chi Sq. Value }=4.095 * * * \\
\text { Gamma }=0.13\end{array}$} & \multicolumn{4}{|c|}{$\begin{array}{c}\text { Chi Sq. Value }=2.214 * * * \\
\text { Gamma }=0.28\end{array}$} \\
\hline
\end{tabular}

Source: Author's own calculations

Note: Figures in Parenthesis are the percentages

$* * *, * *, *$ indicate coefficients are significant at 1,5 , and 10 percent level respectively. 
Table: 3-Multinomial estimation results of financial inclusion in Pakistan, Bangladesh, and India

\begin{tabular}{|c|c|c|c|c|c|c|c|}
\hline & & \multicolumn{2}{|c|}{ Pakistan } & \multicolumn{2}{|c|}{ Bangladesh } & \multicolumn{2}{|c|}{ India } \\
\hline & $\begin{array}{c}\text { Independent } \\
\text { variables }\end{array}$ & B & $\begin{array}{l}\text { Odds } \\
\text { Ratios }\end{array}$ & B & Odds Ratios & B & Odds Ratios \\
\hline \multirow{17}{*}{$\begin{array}{c}\text { Low } \\
\text { financial } \\
\text { inclusion } \\
\text { (LFI) }\end{array}$} & Intercept & 0.037 & & 0.199 & & 0.774 & \\
\hline & Female $=0$ & -0.235 & $0.791 *$ & 0.224 & $0.585 * * *$ & -0.536 & $1.251 * * *$ \\
\hline & Male $=1$ & & & Refe & nce category & & \\
\hline & Age $($ till 30 years $)=1$ & 0.461 & $1.586 * * *$ & 0.407 & $1.252 *$ & 0.225 & $0.666^{* * *}$ \\
\hline & Age $(31-45$ years $)=2$ & 0.141 & $1.151 *$ & 0.607 & $0.622 * *$ & 0.475 & $0.545 * * *$ \\
\hline & $\begin{array}{c}\text { Age (above 45years) } \\
=3\end{array}$ & \multicolumn{6}{|c|}{ Reference category } \\
\hline & Less educated $=1$ & 1.957 & $7.080 * * *$ & 2.329 & $7.378 * * *$ & 1.998 & $10.263 * * *$ \\
\hline & Medium educated $=2$ & 1.60 & $4.952 * * *$ & 1.078 & $2.425 * * *$ & 0.886 & $2.939 * * *$ \\
\hline & Highly educated $=3$ & \multicolumn{6}{|c|}{ Reference category } \\
\hline & Poor $=1$ & 0.675 & $1.965 * * *$ & 1.511 & $2.292 * * *$ & 0.829 & $4.532 * * *$ \\
\hline & $\begin{array}{c}\text { Middle-class } \\
\text { person }=2\end{array}$ & 0.538 & $1.712 * *$ & 0.065 & $1.075^{*}$ & 0.072 & $1.068^{*}$ \\
\hline & Rich $=3$ & \multicolumn{6}{|c|}{ Reference category } \\
\hline & Unemployed =1 & 0.822 & $2.275^{* *}$ & 0.450 & $1.265 *$ & 0.235 & $1.568 * * *$ \\
\hline & Self-employed $=2$ & 0.557 & $1.746 * *$ & 0.064 & $0.824 *$ & -0.194 & $1.066 *$ \\
\hline & $\begin{array}{c}\text { Regular/irregular } \\
\text { salaried employed=3 }\end{array}$ & \multicolumn{6}{|c|}{ Reference category } \\
\hline & Phone not used $=0$ & 1.067 & $2.907 * * *$ & 0.760 & $0.201 * * *$ & 1.607 & $2.138 * * *$ \\
\hline & Phone use $=1$ & \multicolumn{6}{|c|}{ Reference category } \\
\hline \multirow{17}{*}{$\begin{array}{c}\text { Medium } \\
\text { financial } \\
\text { inclusion } \\
\text { (MFI) }\end{array}$} & Intercept & -0.094 & & 0.134 & & 1.290 & \\
\hline & Female $=0$ & -0.659 & $0.517 *$ & 0.008 & $0.989 *$ & -0.011 & $0.992 *$ \\
\hline & Male $=1$ & & & Refe & nce category & & \\
\hline & Age $($ till 30 years $)=1$ & 0.277 & $1.319 *$ & 0.249 & $2.289 *$ & 0.828 & $1.282 *$ \\
\hline & Age $(31-45$ years $)=2$ & 0.033 & $1.033^{*}$ & -0.139 & $1.249 *$ & 0.217 & $0.870^{*}$ \\
\hline & $\begin{array}{c}\text { Age (above 45years) } \\
=3\end{array}$ & \multicolumn{6}{|c|}{ Reference category } \\
\hline & Less educated $=1$ & 0.239 & $1.270 *$ & 1.542 & $2.918 * * *$ & 1.071 & $4.672 * * *$ \\
\hline & Medium educated=2 & 0.517 & $1.677 * *$ & 0.711 & $1.506 * *$ & 0.410 & $2.036 * * *$ \\
\hline & Highly educated=3 & \multicolumn{6}{|c|}{ Reference category } \\
\hline & Poor $=1$ & 0.787 & $2.197 * * *$ & 0.991 & $2.360 * * *$ & 0.859 & $2.694 * * *$ \\
\hline & $\begin{array}{c}\text { Middle-class } \\
\text { person }=2\end{array}$ & 0.809 & $2.245 * * *$ & 0.037 & 1.299 & 0.262 & $1.038 *$ \\
\hline & Rich $=3$ & \multicolumn{6}{|c|}{ Reference category } \\
\hline & Unemployed=1 & 0.396 & $1.486 *$ & 0.349 & $1.181 *$ & 0.166 & $1.418 * * *$ \\
\hline & Self-employed=2 & 0.377 & $1.459 * *$ & -0.179 & $0.787 *$ & -0.240 & $0.836 *$ \\
\hline & $\begin{array}{c}\text { Regular/irregular } \\
\text { salaried employed =3 }\end{array}$ & \multicolumn{6}{|c|}{ Reference category } \\
\hline & Phone not used $=0$ & 0.252 & $0.777 * * *$ & 0.710 & $0.059 * * *$ & 0.675 & $2.034 * * *$ \\
\hline & Phone used=1 & \multicolumn{6}{|c|}{ Reference category } \\
\hline
\end{tabular}

Source: Author's own calculations

Note: The reference category is high financial inclusion

$* * *, * * *$ indicate coefficients are significant at 1,5 , and 10 percent level respectively.

Table 2 depicts frequency distribution and cross-tabulation of an individual's demographic and economic variables with reference to financial inclusion in Pakistan, Bangladesh, and India. In Pakistan, 94.1 percent of women have chances of low financial inclusion, and 82.8 percent of males have low financial inclusion while this percentage is less in India and Bangladesh. The significant value of chi-square represents the relationship and gamma value indicates strong relation of variables. Poor, uneducated population of these countries has more chances of low financial inclusion. The government should promote education and employment opportunities to enhance financial inclusion. 
Table 3 shows the results of the multinomial logistic model which showed that Regarding gender, females prefer low financial inclusion, 0.235 times less than high financial inclusion in Pakistan, females prefer low financial inclusion, 0.224 times more than high financial inclusion in India, and females prefer low financial inclusion, 0.536 times less than high financial inclusion in Bangladesh. This concludes that gender is significant and positively associated with financial inclusion in Pakistan, and Bangladesh. Odds ratios of gender indicate that females of India have more odds to have low financial inclusion as compared to high financial inclusion than Pakistan and Bangladesh. Male persons have more financial inclusion Similar results in past researches (Fungacova \& Weill,2015; Allen et al.,2016). The age is also positive and significantly associated with financial inclusion. Individuals, less than 30 years have more probability to have low financial inclusion. Individuals above thirty to forty-five years have less probability to prefer low financial inclusion than old. This means old persons use more accounts than young ones and results are supported by the number of studies (Abel,2018; Pena et al.,2014; Hoyos et al.,2013). The persons who are less educated have more odds to have less financial inclusion as compared to the reference category. It also shows that if persons are less educated have more probability to have less financial inclusion. Educated persons have more financial inclusion in these countries so education is also positively related to financial inclusion proved by (Abel, 2018; Pena et al., 2014; Cole et al., 2019). Allen et al.,(2016) and Fungacova and Weill( 2015) in China, find that richer and more educated persons are more financially included than poor and less educated. Financially poor persons prefer low financial inclusion, 0.675 times more than high financial inclusion in Pakistan and in India this value is high. Professions also affect the financial access and use of financial services. Self-employed and Salaried persons have more chances to be financially included while unemployed individuals have fewer chances of financial inclusion (J.Sykes et al., 2016). Unemployed preferred low financial inclusion and salaried employed prefer high financial inclusion. Mobile phone users also preferred high financial inclusion proved by George (2012). By using a Multinomial logit model and identified that gender education and wealth of an individual were significant determinates of financial inclusion by using mobile phones.

\section{Conclusion}

The main focus of this study is to identify the nature of the relationship between financial inclusion and its determinants in south Asian countries include Pakistan, India, and Bangladesh. To find out empirical results, we apply the multinomial logistic model and bring several interesting findings that in Pakistan, Bangladesh, and India an educated man, relatively older, rich and a regular employee have a better chance to be financially included. Mobile phone users also preferred high financial inclusion. In Pakistan, India and Bangladesh age, gender, education, financial situation, working type and use of mobile phone all variables have a positive impact on financial inclusion which impacts economic growth. There is a gap that remains for women, uneducated, and unemployed individuals. There is a need to be done more work to improve financial inclusion for women and those who remain financially excluded. There is a gender gap in developing countries; more men own mobile phones than women, preventing them from reaming the full benefits of the technology. Social and cultural barriers are major hurdles for women in the pursuit of financial inclusion in developing countries. Increased financial literacy would help the households to make good decisions regarding financial services As the Endogenous growth model suggests that financial development influences the growth of an economy through savings, investment, and productivity. So physical capital (K) and human capital (L) both play a major role in financial and economic development and we cannot ignore the role of government for the development of the financial sector and overall development of any country. Despite the relationship between the short-run, we should focus on long term results that show a positive and significant relationship between financial development and economic growth in these countries.

\section{References}

Abel-Smith, B. (2018). An introduction to health: policy, planning, and financing. Routledge.

Aduda, J., \& Kalunda, E. (2012). Financial inclusion and financial sector stability with reference to Kenya: A review of the literature. Journal of Applied Finance and Banking, 2(6), 95.

Allen, F., Carletti, E., Cull, R., Qian, J. Q., Senbet, L., \& Valenzuela, P. (2014). The African financial development and financial inclusion gaps. Journal of African economies, 23(5), 614-642.

Asare, S. K., \& Wright, A. (2018). Investors', Auditors' and Lenders' Understanding of the Message Conveyed By the Standard Audit Report, the AICPA Auditing Standards Board (ASB) and International Auditing and Assurance Standards Board (IAASB), September 2009. 
Asare, S. K., Davidson, R. A., \& Gramling, A. A. (2008). Internal auditors' evaluation of fraud factors in planning an audit: The importance of audit committee quality and management incentives. International Journal of Auditing, 12(3), 181-203.

Aterido, R., Beck, T., \& Iacovone, L. (2011). Gender and finance in Sub-Saharan Africa: are women disadvantaged?. The World Bank.

Banerjee, A., Duflo, E., Goldberg, N., Karlan, D., Osei, R., Parienté, W., ... \& Udry, C. (2015). A multifaceted program causes lasting progress for the very poor: Evidence from six countries. Science, 348(6236), 1260799.

Barasinska, N. (2011). Essays on determinants of financial behavior of individuals (Doctoral dissertation).

Barasinska, N. (2011). Essays on determinants of financial behavior of individuals (Doctoral dissertation).

Bruhn, M., \& Love, I. (2013). The Economic Impact of Expanding Access to Finance in Mexico. Banking the World: Empirical Foundations of Financial Inclusion, 137-156.

Chakraborty, A., Wilson, B., Sarraf, S., \& Jana, A. (2015). Open data for informal settlements: Toward a user' s guide for urban managers and planners. Journal of Urban Management, 4(2), 74-91.

Chatterjee, S., Roy, S., Das, A. K., Chattopadhyay, S., Kumar, N., \& Vasilakos, A. V. (2016). Secure biometric-based authentication scheme using Chebyshev chaotic map for multi-server environment. IEEE Transactions on

Dependable and Secure Computing, 15(5), 824-839.

Chattopadhyay, S. K. (2011). Financial inclusion in India: A case study of West Bengal.

Demirguc-Kunt, A., Klapper, L., \& Singer, D. (2017). Financial inclusion and inclusive growth: A review of recent empirical evidence. The World Bank.

Demirguc-Kunt, A., Klapper, L., Singer, D., \& Van Oudheusden, P. (2015). The global findex database 2014: Measuring financial inclusion around the world. The World Bank.

Fungáčová, Z., \& Weill, L. (2015). Understanding financial inclusion in China. China Economic Review, 34, $196-206$.

Goel, S., \& Sharma, R. (2017). Developing a financial inclusion index for India. Procedia computer science, 122, 949-956.

Ismail, F., Shabri Abd. Majid, M., \& Rahim, R. A. (2013). Efficiency of Islamic and conventional banks in Malaysia. Journal of Financial Reporting and Accounting, 11(1), 92-107.

Mas, I., Tiwari, A., Jos, A., George, D., Thacker, K. U. M., Garg, N., ... \& Shukla, V. (2012). Are Banks and Microfinance Institutions Natural Partners in Financial Inclusion?.

McClintock, T. R., von Landenberg, N., Cole, A. P., Lipsitz, S. R., Gild, P., Sun, M., ... \& Noldus, J. (2019). Neoadjuvant Androgen Deprivation Therapy Prior to Radical Prostatectomy: Recent Trends in Utilization and Association with Postoperative Surgical Margin Status. Annals of surgical oncology, 26(1), 297-305.

Park, C. Y., \& Mercado, R. (2018). Financial inclusion: New measurement and cross-country impact assessment. Available at SSRN 3199427.

Pena, X., Hoyo, C., \& Tuesta, D. (2014). Determinants of financial inclusion in Mexico based on the 2012 National Financial Inclusion Survey (ENIF) (No. 1415).

Pena, X., Hoyo, C., \& Tuesta, D. (2014). Determinants of financial inclusion in Mexico based on the 2012 National Financial Inclusion Survey (ENIF) (No. 1415).

Ramiz-ur-Rehman, I. U. M., \& Naseem, M. A. (2017). Emergence of Financial Inclusion in Developing Economies: A Case Study of China and Pakistan. In the 33rd annual conference of PIDE, Islamabad, Pakistan (Vol. 1).

Sarma, M., \& Pais, J. (2011). Financial inclusion and development. Journal of international development, 23(5), 613628.

Sweet, S., Pitt-Catsouphes, M., \& Boone James, J. (2016). Successes in changing flexible work arrangement use: Managers and work-unit variation in a financial services organization. Work and Occupations, 43(1), 75-109.

Sweet, S., Pitt-Catsouphes, M., \& Boone James, J. (2016). Successes in changing flexible work arrangement use: Managers and work-unit variation in a financial services organization. Work and Occupations, 43(1), 75-109.

Sykes, J., Elder, S., Gurbuzer, Y., \& Principi, M. (2016). Exploring the linkages between youth financial inclusion and job creation. Evidence from the ILO school-to-work transition surveys. Geneva, Switzerland: International Labour Organization.

Uddin, A., Chowdhury, M. A. F., \& Islam, M. N. (2017). Determinants Of Financial Inclusion In Bangladesh: Dynamic Gmm \& Quantile Regression Approach. The Journal of Developing Areas, 51(2), 221-237.

Wachira, I. M., \& Kihiu, E. N. (2012). Impact of financial literacy on access to financial services in Kenya. 
Wagiciengo, M. M., \& Belal, A. R. (2012). Intellectual capital disclosures by South African companies: A longitudinal investigation. Advances in Accounting, 28(1), 111-119.

Zhang, Y., Tsang, T. K., Bushong, E. A., Chu, L. A., Chiang, A. S., Ellisman, M. H., ... \& Su, C. Y. (2019). Asymmetric ephaptic inhibition between compartmentalized olfactory receptor neurons. Nature communications, 10(1), 1-16.

Zins, A., \& Weill, L. (2016). The determinants of financial inclusion in Africa. Review of Development Finance, 6(1), 46-57. 